\title{
NREL Geothermal Policymakers' Guidebooks Web site
}

\section{Helping You Create Effective Policy and Increase Geothermal Deployment}

The NREL Geothermal Policymakers' Guidebooks (the Guidebooks) Web site helps guide state and local officials in developing effective policies that support geothermal electricity generation and geothermal heating and cooling technologies.

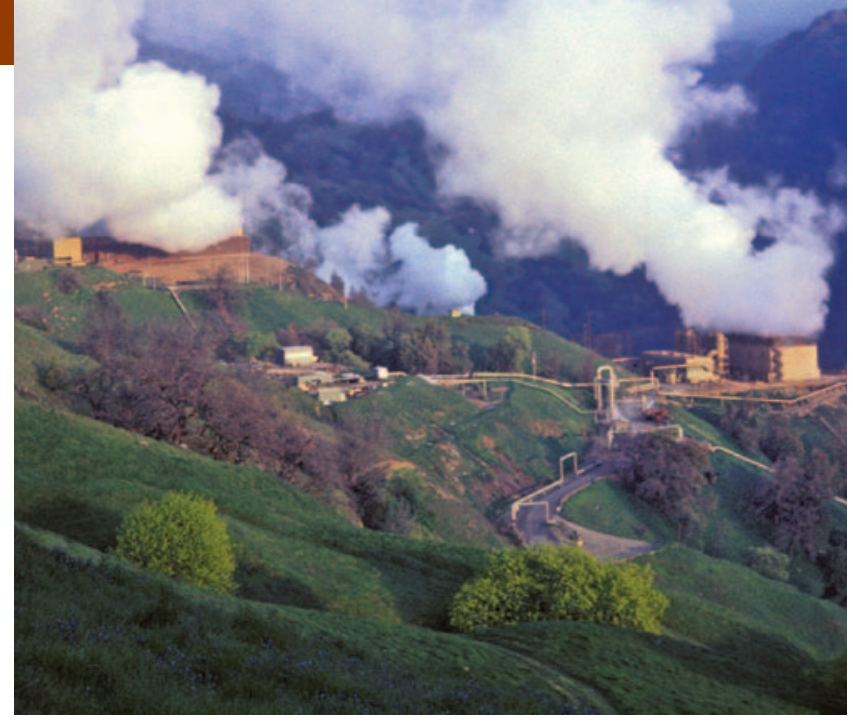

\section{Five Key Steps to Effective Geothermal Policy}

The Guidebooks Web site outlines five key steps for designing effective geothermal policy for your area. Following the steps will help you develop policies that reduce barriers and facilitate market deployment of geothermal technologies.

\begin{tabular}{|c|c|c|c|c|c|}
\hline $\begin{array}{c}\text { STEP } 1 \\
\text { Assess the Local } \\
\text { Industry and } \\
\text { Resource Potential }\end{array}$ & $\begin{array}{c}\text { STEP } 2 \\
\text { Identify Challenges } \\
\text { to Local } \\
\text { Development }\end{array}$ & $\begin{array}{c}\text { STEP } 3 \\
\text { Evaluate Current } \\
\text { Policy }\end{array}$ & $\begin{array}{c}\text { STEP } 4 \\
\text { Consider Policy } \\
\text { Options }\end{array}$ & $\begin{array}{c}\text { STEP } 5 \\
\text { Implement } \\
\text { Policies }\end{array}$ & $\begin{array}{c}\text { Increased } \\
\text { Development }\end{array}$ \\
\hline
\end{tabular}

\section{Step 1: Assess the Local Industry and Resource Potential}

Increasing the use of geothermal energy requires a baseline level of knowledge about the resource potential, industry, and market trends in your locality.

\section{Step 2: Identify Challenges to Local Development}

Identifying specific challenges associated with developing geothermal technologies in your area will help you recognize the point in development where new policy should be targeted.

\section{Step 3: Evaluate Current Policy}

A coordinated plan that addresses current policy gaps and leverages existing state and federal policy will enhance your ability to develop new policy.

\section{Step 4: Consider Policy Options}

New or expanded policies can enhance geothermal deployment. Visit the Guidebooks Web site to learn more about policy options you can consider.

\section{Step 5: Implement Policies}

Choosing and implementing the most appropriate policies for your area will facilitate achievement of geothermal deployment goals. The policies you design should address the most prominent geothermal barriers in your area.

\section{Visit the Web site to Learn More}

Visit the Guidebooks Web site to learn how to develop effective policy today! www.nrel.gov/geothermal/guidebooks

The U.S. Department of Energy's Geothermal Technologies Program (GTP) is soliciting public comments on the Geothermal Policymakers' Guidebooks Web site. Please provide your feedback to GTP by visiting www 1.eere. energy.gov/geothermal/plans/comments. $\mathrm{cfm}$ ?doc=guidebooks. GTP plans to address the public's comments and incorporate them into a final version of the Web site.

National Renewable Energy Laboratory 1617 Cole Boulevard, Golden, Colorado 80401 303-275-3000 • www.nrel.gov

NREL/FS-6A20-49479 • October 2010

Printed with a renewable-source ink on paper containing at least $50 \%$ wastepaper, including $10 \%$ post consumer waste. Credit: USGS/PIX16814 